\title{
Organizational Commitment, Job Redesign, Employee Empowerment and Intent to Quit Among Survivors of Restructuring and Downsizing
}

\author{
Isaiah O. Ugboro \\ North Carolina A\&T State University
}

\begin{abstract}
This study is designed to determine the relationship between job redesign, employee empowerment and intent to quit measured by affective organizational commitment among survivors of organizational restructuring and downsizing. It focused on middle level managers and employees in supervisory positions because survivors of this group are often called upon to assume expanded roles, functions and responsibilities in a post restructuring and downsizing environment. The results show statistically significant positive relationships between job redesign, empowerment and affective commitment. It therefore, provides empirical data to support theoretical models for managing and mitigating survivors' intent to quit and subsequent voluntary turnover among survivors of organizational restructuring and downsizing. The implications of these findings, which suggest expanded roles for job redesign and employee empowerment, are discussed.
\end{abstract}

\section{Introduction}

To cope with increased competitive pressure globalization and demand for efficiency, many organizations have come to rely on the strategy of restructuring and downsizing. The effectiveness of this strategy, however, depends, in part, on its impact on survivors' work attitudes and behaviors. Unfortunately, much of the evidence from research on survivors' work-related attitudes and behaviors subsequent to restructuring and downsizing have documented evidence of feelings of job insecurity, intent to quit, decline in organizational commitment, loyalty and trust, among others (Brockner, 1998; Brockner, Grover, Reed, DeWitt and O'Malley, 1987; Cascio, 1993; Kets de Varies and Balazs, 1997; Armstrong-Stassen, 1998; Ryan and Macky, 1998; Wager, 2001). Of these, intent to quit poses the most serious threat to the effectiveness of the restructuring and downsizing strategy because if unchecked, with appropriate organizational interventions, it leads to voluntary turnover of high performing survivors on whose long-term commitment, motivation and loyalty, the success of restructuring and downsizing depends (Mueller et al. 1984; Mone, 1994; Mishra, Spreitzer and Mishra, 1998). What is more, intent to quit is considered to be one of the most reliable predictors of voluntary turnover (Price and Mueller, 1995; Hom and Griffeth, 1995; Muller et al., 1994). This underscores the need for a conscious and structured organizational approach to the management of survivors' adverse reactions (intent to quit and subsequent voluntary turnover) to restructuring and downsizing.

Using Larzarus and Folkman's (1984) theory of stress, Mishra and Spreitzer (1998) offer a theoretical model that explains survivors' responses to downsizing. It classifies responses as either constructive or destructive and explains how they are influenced by trust, sense of justices, empowerment and job redesign. Empowerment and work redesign, they argue, influence secondary appraisal and facilitate constructive active responses because they enhance survivors' assessments of their capacity to effectively 
respond to the challenges that restructuring and downsizing represent. Consequently, they respond by obeying orders, waiting willingly through good and bad times for conditions to improve in the organization, accepting the goals and objectives assigned to them by management and by actively finding ways to help the organization fulfill the objectives of the downsizing.

If this argument holds true, employee empowerment and job redesign would be related to affective organizational commitment, defined as an employee's desire to remain attached to an organization and work to help accomplish its goal (Porter et al., 1979; Mowday, Steers and Porter, 1979, p. 225). It also suggests that empowerment and job redesign can be organizational interventions that could mitigate "intent to quit" that is induced by the uncertainties that restructuring and downsizing create. This, of course, is based on the premise that constructive responses exhibited by survivors are manifestations of their desire to remain attached and work to help accomplish the goals of the organization. Conversely, intent to quit and the consequent voluntary turnover are manifestations of a decline of survivors' affective organizational commitment. In other words, affective commitment is a predictor of intent to quit and subsequent voluntary turnover.

To date, not enough studies have been done to provide empirical support for the hypothesized relationships in the context of organizational restructuring and downsizing. The objective of this study, therefore, is to examine the relationship between empowerment, job redesign, and intent to quit assessed by affective organizational commitment.

\section{Literature and Hypotheses}

A number of studies on organizational and personal effects of restructuring and downsizing have reported mixed findings. While some reported cost savings and improved efficiency, others have reported high organizational costs in terms of lower levels of employees= morale, trust (Henkoff, 1994; Cascio, 1993; Ket de Vries \& Balazs, 1997; Brockner, Davy \& Carter, 1985) and feelings of job insecurity, higher levels of stress, loss of productive employees and feelings of uncertainties among survivors.

Just as the results are mixed for organizations, survivors' responses to restructuring and downsizing are mixed as well. In one study of survivors' reaction to layoffs, Brockner, Grover, Reed, DeWitt and O'Malley (1987) found that it took the form of reduced work performance and organizational commitment. In another, Brockner, Grover, Reed, and DeWitt (1992) found that survivors who perceived downsizing as a threat but who had high economic need to work, responded by increasing their work efforts. Therefore, while some see it as a threat to job security, breach of psychological contract and trust, others see it as an opportunity to advance and assume greater responsibility by assuming the tasks and responsibilities of the victims. Mishra and Spreitzer's (1998) theoretical model of survivors' response to downsizing classified survivors' responses as either constructive or destructive, active or passive. Constructive responses range from obliging (calm, relief, committed, loyal, following order, routine behavior) to hopeful responses (hope, excitement, optimism, problem 
solving, and taking initiative). Destructive responses ranges from fearful (worry, fear, anxiety, helplessness, withdrawing, procrastinating) to cynical (anger, disgust, moral outrage, cynicism, retaliating) responses. Brockner, Tyler and Cooper-Sneider, 1992; Brockner, Wiesenfeld, Reed, Grover and Martin, 1993; Brockner and Siegel, 1996) have shown that employees= response to restructuring and downsizing is influenced by their perception of justice and fairness of the downsizing and layoff process. They identified three elements of justice (procedural, distributive and interactional) which tend to influence employees' responses. Basically, the findings of this body of work show that survivors who perceive the process to be just and fair to both survivors and victims tend to view it in favorable terms. The reverse seems to be true of those who perceive the process to be unfair and unjust. In their theoretical framework explaining survivors= response to downsizing, Mishra and Spreitzer (1998) hypothesized that survivors' appraisal of their coping capability tends to influence their response to restructuring that involves downsizing and lay offs. They argued that survivors' coping capability is enhanced by employee empowerment and job redesign. They reasoned that because empowerment enhances survivors= sense of personal control, it will facilitate constructive responses to restructuring and downsizing. Similarly, job redesign, because it increases intrinsic job quality, will increase survivors' sense of self-efficacy and capacity to cope with downsizing. This, also, will lead to more active constructive responses to restructuring and downsizing. As yet, there is no sufficient empirical data to support these theoretical relationships. Niehoff et al. (2001) studied these relationships and found positive association between empowerment, job enrichment and employee loyalty in a downsizing environment. This study, however, used loyalty generally and did not distinguish the type and basis of employee loyalty it measured. In a previous study on commitment (a form of loyalty) and employee job performance, Meyer et al. (1989) found that it is the nature of the commitment (loyalty) that counts. This study, therefore, focuses of the affective dimension on organizational commitment.

\section{Work Context and Survivors' Intent to Quit}

The post restructuring and downsizing work environment is characterized by uncertainty, work overload (extent to which the job performance required is excessive, Iverson et al., 1995), role overload (extent to which employees lack the necessary skills to deal with job requirements, Iverson, et al., 1995) and stress level as survivors struggle to assume the work duties and responsibilities of those laid off. Emotional reactions to all of these include, fear, anxiety, feelings of job insecurity, anger, bitter feeling toward the organization for not holding its end of the psychological contract, (feeling let down), and sense of loss of friendly coworkers.

A number of studies have found associations between these prevailing conditions and emotional reactions and intent to quit, and between intent to quit and voluntary turnover. Hom and Griffeth (1995) found positive relationship between role overload and voluntary turnover. Similarly, Mueller, (1994) found association between work overload and voluntary turnover. To some survivors, the job insecurity associated with restructuring and downsizing environment is viewed as an opportunity to pursue career opportunity elsewhere (Bennet et al., 1995). It should be noted, however, that availability of alternative opportunities may mitigate voluntary turnover (manifestation of intent to quit). Unfavorable economic conditions may prevent survivals from translating 
intent to quit into actual voluntary turnover. In such situation, survivors' decision to stay in their current employment may results from continuance commitment.

Empowerment, because of its ability to enhance employees' sense of control and selfefficacy, can be an effective organizational intervention to solve survivors' problem of role overload. Similarly, job redesign, because of its ability to increase the intrinsic job quality, to match employees' skills with job requirement and to increase a job's meaningfulness, it is argued here that intent to quit induced by job insecurity, work and role overload could be reversed or dissipated by empowerment and job redesign, thereby facilitating survivors' desire to remain attached to the organization (organizational commitment). For empowerment and job redesign to be effective, organizational interventions to check intent to quit and the consequent voluntary turnover among survivors, however, they must be positively related to organizational commitment. Therefore it is hypothesized that:

H1: Job redesign (skills variety, Task significance, autonomy, identity and feedback), because it enhances survivors' assessments of their capacity to effectively respond to the challenges of restructuring and downsizing, will be positively related to affective organizational commitment.

H2: Employee empowerment (meaningfulness, impact, competence and selfdetermination), because it enhances survivors' assessments of their capacity to effectively respond to the challenges of restructuring and downsizing, will be positively related to affective organizational commitment.

\section{Organizational Commitment:}

A review of organizational commitment research literature by Meyer and Allen (1991), and corroborated by Dunham, Gruba and Castaneda (1994), identified three types of organizational commitment: affective, continuance and normative.

Affective commitment is defined as employee emotional attachment to, identification with, and involvement in the organization and its goals. It results from and is induced by an individual and organizational value congruency. As a result, it becomes almost natural for the individual to become emotionally attached to and enjoy continuing membership in the organization (March \& Simon, 1958; Hall et. al., 1970; O'Reily \& Chatman, 1986, Meyer \& Allen, 1984). Steers (1977), and Mottaz, (1988), identified factors which help create intrinsically rewarding situations for employees to be antecedents of affective commitment. These factors include such job characteristics as task significance, autonomy, identity, skills variety and feedback concerning employee job performance, perceived organizational support or dependence (the feeling that the organization considers what is in the best interest of employees when making decisions that affect employment conditions and work environment), and the degree that employees are involved in the goal-setting and decision-making processes.

Continuance commitment is defined as willingness to remain in an organization because of personal investment in the form of nontransferable investments such as close working relationships with coworkers, retirement investments and career 
investments, acquired job skills which are unique to a particular organization, years of employment in a particular organization, involvement in the community in which the employer is located, and other benefits that make it too costly for one to leave and seek employment elsewhere.

Normative commitment is induced by a feeling of obligation to remain with an organization. Such a feeling of obligation often results from what Wiener (1982) characterized as "generalized value of loyalty and duty." This is an almost natural predisposition to be loyal and committed to institutions such as family, marriage, country, religion and employment organization as a result of socialization in a culture that places a premium on loyalty and devotion to institutions. This view of commitment holds that an individual demonstrates commitment behavior solely because she or he believes it is the moral and right thing to do. Schwartz and Tessler (1972) identified personal norms as the factor responsible for what Wiener referred to as an internalized normative pressure, that makes organizational commitment a moral obligation because the individual feels he or she ought to do so. This feeling of moral obligation is measured by the extent to which a person feels that he or she should be loyal to his or her organization, make personal sacrifice to help it out and not criticize it (Wiener and Verdi (1980).

Common to all of the three types of commitment is the view that commitment is a psychological state that (a) characterizes the employee's relationship with the organization, and (b) has implication for the decision to continue or discontinue membership in the organization. Employees with a strong affective commitment remain with an organization because they want to, those with a strong continuance commitment remain because they have to, and those with a strong normative commitment remain because they feel they ought to (Meyer, Allen and Smith (1993). Allen and Meyer (1990), found, however, that these three classifications of commitment are conceptually and empirically separable. Even though there appears to be some overlap between affective and normative commitment, both were found to be relatively independent of continuance commitment. Therefore, they can be measured separately.

Over the years, two basic approaches have been used to study organizational commitment: commitment-related attitudes and commitment-related behaviors. Each approach offers a slightly different definition. The commitment-related attitude approach defines organizational commitment as a partisan, affective attachment to the goals and values, and to the organization for its own sake, apart from its purely instrumental worth (Buchanan, 1974, p. 533). Porter, Crampton and Smith (1976) define it as the willingness of an employee to exert a high level of effort on behalf of the organization, a strong desire on behalf of the organization, and an acceptance of its major goals and values. According to Mowday, Steers and Porter (1979, p. 225), attitudinal commitment represents a state in which an individual identifies with a particular organization and its goals and wishes to maintain membership in order to facilitate these goals.

The commitment-related behavior approach focuses on a behavioral pattern guided by internalized normative pressures to act in a way that meets organizational goals and interest (Wiener, 1982). Wiener and Gechman (1977) argued that the pattern of behavior resulting from commitment should possess the following characteristics: (1) it 
should reflect personal sacrifices made for the sake of the organization; (2) it should show persistence - that is, the behaviors should not depend primarily on environmental controls such as reinforcements or punishment, and (3) it should indicate a personal preoccupation with the organization, such as devoting a great deal of personal time to organization-related actions and thoughts. In this sense, organizational commitment is viewed as (1) willingness of an individual to identify with and the desire not to leave an organization for selfish interest or marginal gains; (2) willingness to work selflessly and contribute to the effectiveness of an organization; (3) willingness to make personal sacrifice, perform beyond normal expectations and to endure difficult times with an organization-- low propensity to "bail-out" in difficult times (4) acceptance of organization's values and goals -- the internalization factor. This study adopted the organizational commitment behavior-related approach.

\section{Employee Empowerment}

One of the most frequently referenced definitions of employee empowerment is that offered by Conger and Kanungo (1988). They define empowerment as a process of enhancing feelings of self-efficacy among organizational members through the identification of conditions that foster powerlessness, and through their removal by both formal organizational practices and informal techniques of proving efficacy information. This definition implies strengthening the effort-to-performance expectancy or increasing employee feeling of self-efficacy. According to Conger and Kanungo, the effect of empowerment is the initiation and persistence of behavior by empowered employees to accomplish task objectives. This definition is rooted in management theory of power and authority delegation that gives an employee the right to control and use organizational resources to bring about desired organizational outcomes.

Thomas and Velthouse (1990), however, argued that the concept of empowerment is much more complex and could not be fully explained in a one dimensional construct such as self-efficacy. They therefore define empowerment as an intrinsic task motivation that manifests itself in four cognitions (meaningfulness, competence, impact and choice or self-determination), reflecting an individual's orientation to his or her work roles. By intrinsic task motivation, they mean, a positively valued experiences that an individual derives directly from a task that produces motivation and satisfaction.

Meaningfulness is the value of the task goal or purpose in relation to the individual's own ideals or standards, and competence is the degree to which a person can perform task activities skillfully. Impact, on the other hand, is the degree to which behavior is seen as making a difference in terms of accomplishing the purpose of the task, while choice or self-determination is the causal responsibility for a person's actions. It reflects independence in the initiation and continuation of work behavior and processes (Deci, Connell, and Ryan, 1989).

Employee empowerment literature identifies contextual factors and strategies that promote and support empowerment. For example, Burke (1986) suggests that a way to empower employees is to express confidence in them together with establishing realistic high performance expectations for them. Block (1987) adds the creation of opportunities for employees to participate in decision making, and giving employees 
autonomy from bureaucratic constraints as empowerment strategies. Comparatively, Benis and Nanus (1985) suggest the setting of performance objectives for employees that are challenging and inspiring. Also, Oldham (1976), Kanter (1979), Strauss (1977), Hackman and Oldham (1975) suggest performance-based reward systems and enriched jobs that provide autonomy and control, task identity, opportunities for career advancement and task meaningfulness as ways to empower employees. At the organizational level, however, McClelland (1975) and House (1988) suggest that empowerment could be achieved through employee selection and training programs designed to provide required technical skills together with a culture which encourages self-determination and collaboration instead of competition.

A practical and process oriented definition of empowerment was offered by Bowen and Lawler (1992). They define employee empowerment as sharing with front-line employees, information about an organization's performance, information about rewards based on the organization's performance, knowledge that enables employees to understand and contribute to organizational performance, and giving employees the power to make decisions that influence organizational direction and performance. According to Zemke and Schaaf (1989), employee empowerment means turning the front-line loose, and encouraging and rewarding employees to exercise initiative and imagination.

\section{$\underline{\text { Job Redesign }}$}

For over three decades, much of the research on job design and redesign has been based on the work of Hackman and Oldham $(1976,1980)$. They argued that the intrinsic value and motivating potential of a job are based on certain task dimensions: task variety, autonomy, identity, significance feedback and skills variety. It is generally assumed that a job that is high on these dimensions or attributes has a higher motivating potential than a job that is not. Even though Salancik and Pfeffer (1978) added the role of individual differences, Hackman and Oldham's task dimensions or attributes remain the focus of much of the research on job design or redesign (Griffin, Welsh and Moorhead, 1981).

Griffin (1982b, 1991) studied the effects of work redesign on employee perception, attitudes and behaviors and found positive and desired association between work redesign and attitudes (job satisfaction and commitment), and increased productivity. The objective of these studies was to establish the role of work redesign as a change intervention for enhancing employees' work experiences. It should be noted, however, that the organizational context of these studies was free of organizational dynamics which restructuring and downsizing create. Since the survivors' syndrome exacts a different kind of influence on employees' perception, attitudes and behaviors, this study, because it is done in a post restructuring and downsizing organizational environment, is likely to produce results which the Griffin study may not have captured.

Mishra and Spreitzer (1998), identified job variety and autonomy as two attributes of Hackman and Oldham task dimensions as relevant to intrinsic job quality in the context of restructuring and downsizing. They reasoned that as a result of restructuring and downsizing, survivors are asked to assume some of the duties and responsibilities of 
those who are laid off. Therefore, survivors often need additional skills and resources to cope with the increased variety of their job. These new skills and resources may in turn reduce their sense of job insecurity. Secondly, they argued that job autonomy becomes more important if survivors are expected to assume more decision-making roles as more decisions are driven down when the organizational structure is delayered as a result of restructuring and downsizing. They reasoned that when survivors have more autonomy in decision making and have more choice of how to do their jobs, they are likely to feel more in control and are better able to cope.

A notable concern of many survivors of organizational restructuring, downsizing and layoff is inability to absorb and cope with increased work load. However, survivors' ability to cope with increased work load that often results from restructuring is not often given serious attention because for the most part, much of management's attention is on how to survive the transitional period (Cameron et. al, 1993). Meanwhile, survivors' level of intrinsic job satisfaction suffers. It is therefore argued by Brockner, Grover, Reed and Dewitt (1992), that job redesign that enhances the intrinsic job quality is necessary to help survivors cope with increased job scope and depth. Mishra and Spreitzer (1998) suggested that the extent to which survivors' job has been changed as earlier noted by Brockner and Wiesenfeld (1993), will influence their response to downsizing. They further theorized that survivors who lack the ability and resource to perform their newly assigned duties or job effectively are more likely to negatively respond to restructuring and downsizing. The objective of any job redesign following restructuring and downsizing, therefore, is to restore intrinsic job quality to pre-restructuring level or increase it from pre-restructuring level. In this way, as Brockner, Wiesenfeld, Reed, Grover and Martin (1993) argued, survivors' attention can be focused on coping with the demands of their increased job scope that often require a variety of skills as a result of downsizing or restructuring instead of being distracted, consumed and often frustrated by it.

\section{Methodology}

\section{Construct measurement}

Jobs redesign: Job redesign was measured by asking participants to indicate the importance of changing certain characteristics of their current jobs. These were task variety, skills variety, task identity, task autonomy, feedback, and others. Other than task autonomy, each measure is identified by a one-item statement. For example, task variety is assessed by the opportunity to perform a variety of tasks, skill variety by opportunity to use a variety of skills on a job, task identity by an opportunity to complete an entire task an employee can call his own, and feedback by a job in which an employee can tell how well he is doing. The two statements regarding task autonomy are the freedom management gives employees to perform their jobs in ways they see fit, and freedom to schedule own work. The other item statements in job design are opportunity to work with cooperative employees, and additional training and technology to handle the demands of a job. Together, a seven-item statement scale was used to determine the job characteristics respondents consider important to their job performance. They were asked to base their responses upon the following five-point Likert scale: 1 - very unimportant, 2 - unimportant, 3 - neither important nor unimportant, 
4 - important, and 5 - very important. For job redesign, the scale items came from the work of Hackman and Oldham $(1976,1980)$.

Employee empowerment: Adopting a synthesis of the definitions offered by Thomas and Velthouse (1990), Conger and Kanungo (1988), and Mishra and Spreitzer (1998), employee empowerment was measured in four dimensions. The first, meaning - the value of a work objective compared with one's ideals or standards. The second, competence -- An individual's conviction or confidence in his or her ability or effectiveness in accomplishing the performance requirements of a task. The third, Selfdetermination -- An employee's independence in the initiation and continuation of work behavior and processes (Deci, Connell, and Ryan, 1989). The fourth is impact which refers to the degree to which an individual can influence work-related outcomes. Each measure of empowerment was assessed by a three-item statement giving twelve statements together (Ashford, Lee \& Bobko, 1989), Respondents were asked to express their agreements or disagreements using the Likert scale: Strongly disagree $=$ 1 , disagree $=2$, neither agree nor disagree $=3$, agree $=4$, strongly agree $=5$. Meaningfulness of a job to an employee $(\alpha=0.89)$ is assessed by asking employees how important to them is the work they do. Competence $(\alpha=0.74)$ is assessed based upon an employee's ability to do a job, if an employee feels self-assured to do a job, and mastery of the skills necessary to do a job. Self-determination $(\alpha=0.80)$ is in terms of how one does a job, opportunities for independence, freedom and significant authority in determining how a job is done. Finally, the impact of an employee in an organization $(\alpha=0.86)$ is assessed in terms of the influence and control one has over what happens in one's department.

Affective organizational commitment: Affective commitment was measured by statements that indicate an employee emotional attachment to, identification with, and involvement in the organization and its goals in terms of (1) willingness of the individual to identify with and the desire not to leave an organization for selfish interest or marginal gains; (2) willingness to work selflessly and contribute to the effectiveness of an organization; (3) willingness to make personal sacrifice, perform beyond normal expectations and to endure difficult times with an organization -- low propensity to "bail-out" in difficult times (4) acceptance of organization's values and goals -- the internalization factor. Survey respondents were to show their levels of agreement to statements about affective commitment using a five-point Likert scale: 1 - strongly disagree, 2 - disagree, 3 - neither agree nor disagree, 4 - agree, 5 - strongly agree. It should be noted that only measures of affective commitment were used as surrogate for survivors' constructive responses.

Affective commitment is measured using a scale containing six statements, out of the set provided by Meyer, Allen and Smith (1993). Two examples of the statements in the affective commitment scale $(\alpha=0.89)$ are if employees would be happy to spend the rest of their careers with the agency, and if they felt the agency's problems were their own. 


\section{Study Sample and Questionnaire}

At the planning stage of this study, eight transit systems were invited to participate based on the author's knowledge of their involvement in outsourcing, restructuring and downsizing. In the letter of invitation, the objectives and motivation for the study were stated. Of the eight systems that were invited, five agreed to participate. Of the five, two are considered small, operating fewer than one hundred buses. One is considered to be medium size, operating 350 buses. The remaining two are among the largest in the United States. Both operate rail and bus services with more than 2000 vehicles in maximum service.

Middle level managers and employees in supervisory positions were selected to participate in the study because this group tends to be the focus of most of the organizational restructuring and downsizing in recent years. Also survivors among this group are often called upon to assume expanded roles, functions and responsibilities in a post restructuring and downsizing environment. Additionally, they are more likely to be responsible for implementing the restructuring and post restructuring management strategies. As a result, they are in better position to observe and experience the work behaviors and attitudes of survivors. It is hoped that this would provide more realistic and reliable data and information about the impact of restructuring and downsizing on themselves and those they supervise. Moreover, because past studies seldom focused on them, they offer a unique opportunity to understand how to manage survivors' responses to organizational changes. Therefore, the findings regarding this group should add another perspective to the management literature on empowerment, job redesign and intent to quit measured by affective organizational commitment in the context of restructuring and downsizing.

The study questionnaire utilized measures of job redesign, affective organizational commitment and employee empowerment with established validity (Mowday, Steers and Porter, 1979; Allen and Meyer, 1990; Hackman and Oldham, 1976; Thomas and Velthouse, 1990). With appropriate instructions for each section of the questionnaire, participants were asked to express their level of agreement or disagreement with measures of affective organizational commitment and employee empowerment. In the case of job redesign, they were asked to express the degree of importance or unimportance they attached to each job redesign characteristic. The questionnaire also solicited information on the demographic characteristics of the respondents.

The questionnaires were mailed with postage-paid return envelopes to participants whose organizations had agreed to participate in the study. Upon completion of the questionnaire however, each participant was asked to mail it directly to the study author. All were assured of the confidentiality of their responses. Overall, 700 questionnaires were distributed. Of these 438 usable ones were returned, for an effective response rate of $62 \%$. On the average, the respondents were well educated with 3.14 years of postsecondary education, had been with their transit systems for 14.4 years. Additionally, $75 \%$ identified themselves as white, $42 \%$ were female and $46 \%$ were married. 


\section{Statistical methods}

The statistical methods used in the analyses are factor analyses to test the validity of the measures, Pearson correlation to assess the relationships or association between the scale items and constructs, and Cronbachs alphas to test for the reliability of the scales. These tests were performed against the alternative one-factor model which is the usual procedure for testing convergent and discriminant validity (Lee, Pillutla \& Law, 2000). The test statistics are based upon $x^{2}$, its significance level, the Tucker-Lewis reliability index (TLI), and the squared canonical correlations that represent the percentage of the variation in each factor explained by the items.

\section{Results}

Table 1 shows the statistical results for job redesign analysis. The terms in the parentheses are the probabilities. Evident from the table are the high scores showing that if given the opportunity, employees who participated in this study expressed the desire to change some of their job features. The feature employees consider most importantly to change is skills variety (mean $=4.3256$ ). This is followed closely by task autonomy in terms of freedom to perform their jobs in some manner they see fit (mean = 4.2558), and a job with self-assessment feedback built into it (mean $=4.1977$ ). Next is an opportunity to experience a sense of community by working with cooperative workers (mean $=4.1628$ ), and additional training and technology to handle the demands of their jobs (mean $=4.1628$ ). Task autonomy in terms of freedom to schedule own work (mean $=4.0223$ ), and task identity (mean $=3.9844$ ), are also important to employees in terms of job redesign. The low standard deviations show that there is not a wide variation in the responses, and that the results are nearly consistent across employees.

Consistency of results across observations drawn from various populations is shown by the high Cronbach's alphas in the table. Overall, our measure of job redesign has an alpha value of 0.6574 that is also within the acceptable range for established scales.

Beside the mean, standard deviations and the alphas, the table shows the correlations between the items in the scale and the significance levels of the correlations in parentheses. While most of the correlations are statistically significant at the 0.05 level, a considerable number is not. In particular, the responses regarding opportunity to experience a sense of community by working with cooperative employees has no statistically significant relationship with any of the other items in the scale except feedback. Also, feedback is not statistically related in a significant way to most of the other items in the scale. The exception is the relationship between feedback and skills variety. Therefore, it appears from these results that at least from this study, one cannot generalize about the relationships between the responses regarding feedback and an opportunity to work with cooperative employees on one hand, and the remaining scale items on the other. These responses are unrelated so a strategy to improve one will not be associated with the other. However, for the scale items whose responses are significantly correlated, a strategy to improve one will be associated with a positive outcome in the other. 
Table 2 shows the results of empowerment analysis, using the four dimensional definition. Consistent with the other findings from job redesign analysis discussed earlier, the mean and alphas are high with low standard deviations and show high reliability. Furthermore, they show that most of the respondents strongly agree that their jobs are meaningful to them. They also feel very competent in doing their jobs, exhibit self-determination in job performance, and recognize their values to their organizations in terms of their impacts in their departments.

It is observed in the table, however, that the respondents do not agree as strongly about self- determination and their impacts as they do about their competence to perform their jobs and the meaningfulness of their jobs to them. However, examination of the correlations between the scales items shows that they are highly significant. This suggests that the respondents are not divided about their levels of agreement to the scale items.

The table also shows statistically significant positive association between competence and self-determination. The correlation between them is 0.3126 with $p>0.003$. Similarly, a statistically significant relationship is found between self-determination and the impacts respondents feel they have in their departments; here, the correlation is 0.4461 with $p>0.001$. Given these results, it is deducible that employees who strongly feel empowered are likely to be those who strongly feel competent (self- efficacy) in their jobs, or feel they have strong impacts in their departments, or have very strong self-determination. This relationship provides added empirical support for the four dimensional conceptualization of empowerment, meaningfulness, competence, impact and choice or self-determination.

Regarding the stability of the four measure of empowerment, the question that arises is: can these four measures be statistically replicated? This was answered by a confirmatory factor analysis. A factor analysis of all of the twelve items and requesting for a four-factor solution was done, since we have four measures. If the original four measures of empowerment are stable, then the same statements in each measure would load on one factor. If they are not, the statement will expected to load heavily on different factors. The results of the factor analysis in Table 2 clearly confirm that with a four-factor solution, the scale items load on the factors as expected. The impact items load heavily on factor one, the meaningfulness items on factor two, the selfdetermination items on factor three, and the competence items on factor four. Therefore, the four measures are truly independent and cannot be combined into a single measure of empowerment.

Other questions of interest are: Are those who express a strong sense of self-efficacy the same as those who see themselves as having strong impact in their department? Are those strongly agreeing that they have self-determination the same as those who strongly agree that their jobs are meaningful? Answers to these questions were sought as a part of this analysis by first calculating the mean scores for the measures of empowerment for each respondent, and determining the correlations between them. Correlation analysis did not find associations among all measures of empowerment. However, a statistically significant positive association between competence and selfdetermination was found. The correlation between the two is 0.3126 with $p>0.003$. 
Similarly, a statistically significant relationship was found between self-determination and the impacts of employees in their departments; here, the correlation is 0.4461 with $p>0.001$. Given these results, it is deducible that employees who strongly feel empowered are likely to be those who strongly feel competent (self efficacy) in their jobs, or feel they have strong impacts in their departments, or have very strong selfdetermination.

Table 3 shows the analysis responses to measures of affective commitment. It shows descriptive statistics and the correlations between the statements. Examining the table, the alpha values are obviously more than 0.8877 , which is very high, and fall within the acceptable range for an established scale. The mean values show a higher level of affective commitment. Apart from statement number 2 with mean value of 2.6180, most of the respondents agree that they have affective commitment to their organizations but do not, however, consider the problems of their organizations as their own.

\section{Results of Hypotheses Test}

Table 4 presents the results of correlation analysis between measures of job redesign, employee empowerment and organizational commitment ( survivors' constructive response to organizational restructuring and downsizing). While the composite measure of job redesign does not have statistically significant association with organizational affective commitment or constructive and hopeful response to organizational restructuring and downsizing, there are statistically significant correlations between measures of employee empowerment (impact, meaningfulness and competence) and constructive and hopeful responses to structuring and downsizing. This is in agreement with hypothesis 2. Therefore hypothesis 2 is accepted. There is some evidence to support hypothesis 1 because, as the results show, job redesign that enhances job meaningfulness is associated with employee sense of empowerment, and since there is a significant association between affective commitment and meaningfulness, one can conclude that, even though limited, job redesign could enhance or facilitate survivors' constructive and hopeful responses to restructuring and downsizing. Therefore, there is some evidence to accept hypothesis 1 as well.

\section{Discussion and Conclusion}

This study addresses an important problem among survivors of organizational restructuring and downsizing. Intent to quit and subsequent voluntary turnover pose a serious threat to effectiveness of the restructuring strategy. While the topic of organizational commitment, empowerment and job design have received considerable attention in the organizational behavior literature, their integration into the emerging downsizing and restructuring survivor literature needs more attention.

Much of the previous studies on survivors' reactions and responses to downsizing or restructuring have focused on the roles of prior commitment, institutional fairness, sense of justices and trust. Very few (Iverson and Pullman, 2000; Niehoff et al., 2001; Spreitzer and Mishra, 2002) have studied the relationship between empowerment, job enrichment and survivors' organizational commitment, loyalty voluntary turnover. Therefore, this study which examined empowerment, job redesign, intent to quit through 
affective organizational commitment contributes to this emerging stream of research on this understudied area of the survivor literature.

There are, however, emerging theoretical models (Mishra and Spreitzer, 1998) on how to facilitate survivors' hopeful and constructive response to restructuring and downsizing but because they are new and lack the empirical evidence to support their application. This study provides such empirical evidence that supports these theoretical models. It shows that both job redesign employee empowerment that enhance survivors' sense of impact and job meaningfulness can facilitate survivors' affective commitment and reduce the intent to quit because of the significant positive correlation between them. If survivors' affective commitment is enhanced we can expect it to positively reflect on morale, sense of job security and productivity. This, therefore, suggests an expanded role for job redesign and empowerment beyond their traditional application.

The finding of significant negative correlation between competence and affective commitment indicates that highly competent survivors have a high propensity to leave an organization subsequent to restructuring and downsizing. It is supported by Mishra, Spreitzer and Mishra (1998) and by Reichheld, (2001) who found that high potential survivors, because they have attractive employment alternatives, are more likely to leave the uncertainties of a downsizing environment for better job opportunities elsewhere. It, therefore, underscores the need for organizations to pay attention to the content and context of survivors' job s to make sure they enhance their sense of impact and task meaningfulness. This is particularly important since an organization's ability to realize the performance objectives of restructuring and downsizing depends, to a very great extent, on the morale, commitment and productivity (constructive responses) of survivors.

Fewer studies in the survivors' literature have focused on survivors in nonmanagement position than those in management and supervisory positions. The need to focus on managers and supervisors has emerged in recent years for two reasons. First, earlier waves of lay offs targeted employees in non- managerial positions. In recent years, however, the focus has shifted to middle level managers and supervisors as organizations are delayered in an effort to reduce bureaucracy and administrative costs. As a result, they are now more vulnerable to restructuring and downsizing than those in nonmanagement positions (Cappelli, 1992). Secondly, those who survive are expected to champion the implementation of the restructuring and downsizing strategy, and as their work load increases, stress level will also, making them more susceptible to burnout, a work condition that heightens intent to quit and subsequent voluntary turnover. Additionally, on the average, public-sector managers (who are studied here) are less prepared to meet the challenges of organizational change such as restructuring and downsizing than the average manager in the private sector (Verma and CutcherGershenfeld, 1996).

These findings, contribute to the job redesign and empowerment literature in a number of important ways. First, they add validity to the theoretical conceptualization that job redesign that enhances an employee's sense of impact and meaningfulness (task significance), competence (skills variety) and self-determination (autonomy) gives a sense of empowerment and an enhanced coping capacity which facilitate constructive 
responses. Secondly, they are consistent in some areas with Niehoff et. al. (2001), who found positive relationship between job enrichment, empowerment and employee loyalty in a downsizing environment and with Spreitzer and Mishra (2002), who found that empowerment facilitates survivors' attachment (affective commitment) which, in turn, leads to a lower level of voluntary turnover among survivors in the years following downsizing.

\section{Managerial Implications:}

A recent survey of 759 survivors in organizations that have restructured and downsized indicates that the formulation of appropriate management strategies or interventions to response to survivors' adverse reaction (intent to quit, voluntary turnover, etc.) remains a challenge (Anderson \& KS\&R, 2001). Moreover, Cascio (1993) attributed the failure to realize the potential and anticipated benefits of restructuring and downsizing in many organizations, partly, to the lack of effective strategies to mitigate their organizational and personal consequences. Isabella (1989) noted that while organizations are usually prepared to meet the needs of those being laid off, they are often unprepared for the strong emotions, lengthy adjustment period, diminished morale and lower productivity often experienced and expressed by survivors.

The results of this study provide managers some guidance on how empowerment and job redesigned strategies can be applied to the problem of intent to quit and subsequent voluntary turnover among survivors whose motivation, commitment and loyalty are needed to accomplish the organizational objectives of restructuring and downsizing. By increasing survivors' sense of personal control through empowerment and reducing incidences of work and role overload through job redesign, as suggested by this study, managers can apply both as organizational interventions to check the exodus of high performing survivors. It highlights the role of empowerment as a strategy or an intervention that strengthens an employee's self-efficacy or confidence in accomplishing task objectives. Managers are, therefore, encouraged to formulate and implement empowerment policies that encourage employees to respond to work-related problems and to provide them the resources and authority to do so. These policies, according to Colzon (1987), should free employees from the rigorous control by instruction, policies, and orders and give them the freedom to take responsibility for their ideas, decisions and actions, while releasing hidden resources to them.

\section{Study Limitation}

The first potential limitation of this study is that it captures a single period in time as compared to a longitudinal study that would capture the effect of time. Two studies (Allen et al., 2001; Armstrong-Stassen, 2002) examined the moderating effects of time on survivors' reactions. Both studies reported significant decline in work attitude and behaviors initially; however, modest improvement in perceptions of job insecurity, organizational commitment, morale and work behaviors were observed over time. None of the studies mentioned any organizational interventions which may have contributed to the modest behavioral changes that were observed. Despite the improvement, Armstrong-Stassen concluded that the impacts of restructuring or downsizing tend to last a long time. Therefore, a follow-up study is needed to determine whether these 
organizations actually experienced involuntary turnover as a manifestation of intent to quit. However, such a study must take into account the economic conditions such as availability of alternative employment opportunities that would facilitate the manifestation of intent to quit into actual involuntary turnover. If the economic environment does not provide alternative employment opportunities, then a decline in the level of affective commitment and an increase in continuance commitment levels could be used as surrogate measures on a manifestation of intent to quit. A second limitation is failure to consider the moderating effect of demographic variables. Iverson and Pullman (2000) studied the moderating effects of demographic variables on intent to quit and subsequent voluntary turnover. They found that younger employees in white collar positions (managers perhaps) with intent to quit were more likely to actually leave the downsized environment. Lastly, another factor that could have a moderating effect on intent to quit is the general economic conditions that determine availability of employment opportunities. Obviously, during difficult economic conditions, intent to quit is not often translated into actual voluntary turnover. Because of what we know from other studies on these areas, the findings of this study are still valuable when taken to proper context. The failure of this study to consider these factors does not, however, compromise the findings, particularly the attention it brings to the problem of intent to quit and subsequent voluntary turnover in a downsizing environment. Also, the study does not consider the issue of directionality. However, the existence of significant correlation between variable suggests that one could be used to influence the other.

\section{References}

Allen, N. J. \& Meyer, J. P., 1990. The measurement and antecedents of affective, continuance, and normative commitment. Journal of Occupational Psychology, 63: 1-18.

Armstrong-Stassen, M., 1998. Downsizing the federal government: A longitudinal study of managers' reactions, Canadian journal of Administrative Sciences, 15(4): 310-321

Ashford, Susan J., Lee, Cynthia, and Bobko Phillip, 1989. Content, causes, and consequences of job insecurity: A theory-based measure and substantive test. Academy of Management Journal, 32(4): 803-829.

Bennet, N., Martin C. L., Bies, R. J., \& Brockner, J. 1995. Coping with a layoff: A longitudinal study of victims. Journal of Management, 21(6): 87-117.

Benis, W. \& Naus, B. 1985. Leaders, New York: Harper \& Row.

Block, P. 1987. The empowered manager, San Francisco, Jossey Press

Bowen, David E. \& Lawler III, Edward E. 1992. The empowerment of service workers: What, why, how and when, Sloan Management Review, 33(3): 31-39

Brockner, J., Tyler, T. R. and Cooper-Schneider, Rochelle, 1992. The influence of prior commitment to an institution on reactions to perceived unfairness: The higher they are, the harder they fall. Administrative Science Quarterly. 47: 241-261. 
Brockner, J., Grover, S. L., \& Blonder, M. D. 1988. Predictors of survivors' job involvement following layoffs: A field study. Journal of Applied Psychology, 73: 436-442.

Brockner, J., Grover, S. L., Reed, T. F., DeWitt, R. L., \& O'Malley, M. N. 1987. Survivors' reactions to layoffs: We get by with a little help for our friends. Administrative Science Quarterly, 32: 526-541.

Brockner, J., Grover, S. L., Reed, T. F., \& Dewitt. R. L. 1992. Layoffs, job insecurity and survivors' work effort: Evidence of inverted-U relationship. Academy of Management Journal, 35: 413-425.

Brockner, J. \& Wiesenfeld, B. M. 1993. Living on the edge of social and organizational psychology: The effects of job layoffs on those who remain. In J. K. Murninghan (Ed.), Social psychology in organizations: Advances in theory and research. Englewood Cliff:, NJ: Prentice-Hall.

Brockner, J. , Wiesenfeld, B. M., Reed. T. F., Grover, S. \& Martin, C. 1993. Interactive effect of job content and context on the reaction of layoff survivors. Journal of personality and Social Psychology, 64: 187-197.

Brockner, J. and Cooper-Schneider, R. 1992. The influence of prior commitment to an institution on reactions to perceived unfairness; The higher they are, the harder they fall. Administrative Science Quarterly. 47: 241-261.

Brockner, J., Davy, J., \& Carter, C. 1985. Layoffs, self-esteem, and survivor guilt: Motivational, affective, and attitudinal consequences. Organizational Behavior and Human Decision Processes, 36: 229-244.

Brockner, J., \& Siegel, P. A. 1996. Understanding the interaction between procedural and distributive justice: The role of trust. In R. M. Kramer \& T. R. Tyler (Eds.), Trust in organizations: Frontiers of theory and research: 390-413. Thousand Oaks, CA: Sage.

Buchanan, B. II, 1974. Building organizational commitment: The socialization of managers in work organizations, Administrative Science Quarterly, 22: 533-546.

Burke, W. 1986. Leadership as empowering others, In S. Srivastra (Ed.), Executive Power . San Francisco, Jossey-Bass. 51-77.

Burke, R., 1998. Downsizing and Restructuring in Organizations: Research Findings and Lessons Learned - Introduction." Canadian Journal of Administrative Sciences 15: 297-99.

Cameron, K. S., Freeman, S. J., and Mishra, A. K. 1993. Organizational downsizing. In G. Huber and W. Glicks (Eds.), Organizational change and redesign: Ideas and insights for improving performance. New York: Oxford University press

Carmeron, K. S., Freeman, S. J., \& Mishra, A. K. 1991. Best practices in white-collar downsizing: Managing contradictions. Academy of Management Executive, 5(3): 57-73. 
Cascio, W. F. 1993. Downsizing: What do we know? What have we learned? Academy of Management Executive, 7(1): 95-104.

Cobb, S., \& Kasl, S. V. 1977. Termination: The consequences of job loss. Publication No. 77-224, National Institute of Science and Health. Washington, D. C.: Department of Health, Education, and Welfare.

Colzon, J. 1987. Moments of Truth, New York: Ballinger.

Conger, J. A. and Kanungo, R. N. 1988. The empowerment process: Integration theory and practice, Academy of Management Journal, 13 (3): 471-482.

Deci, E. L., Connell, J. P. and Ryan, R. M. 1989. Self-determination in a work organization. Journal of Applied Psychology, 74: 580-590

Dunham, Randall B., Grube, Jean A. \& Castaneda, M. B.1994. Organizational commitment: The utility of an integrative definition. Journal of Applied Psychology, 79(3): 370-380.

Griffeth, R. W., Hom, P. W., \& Gaerner, S., 2000. A meta-analysis of antecedents and correlates of employee turnover: update, moderator, and research implications for the next millennium. Journal of Management, 26: 463-488.

Griffin, R. W., Welsh, M. A., \& Moorhead, G. 1981. Perceived task characteristics and employee performance: A literature review. Academy of management Review, 6: 655664.

Griffin, R. W, 1982b. Perceived task characteristics and employee performance, Human Relations, 35: 927-938.

Griffin, R. W., 1991. Effects of work redesign on employee perceptions, attitudes and behaviors: a long-term investigation, Academy of Management Journal, 34 (2): 425-435.

Hackman, J. R., \& Oldham, G. 1976. Motivating through the design of work: test of a theory. Organizational behavior and performance, 16: 250-279.

Hackman, J. R., \& Oldham, G. 1980. Work Redesign. Reading MA: Addison-Wesley.

Hackman, J. R, Oldham, G. R., Janson, R., \& Purdy, K. 1975. New strategy for job enrichment, California management Review, 17(4): 65-75

Hall, D. T., B. Schneider \& Nygren, H. T. 1970. Personal factors in organizational identification. Administrative Science Quarterly, 15: 176-190.

Henkoff, R. 1994. Getting beyond downsizing. Fortune, January 10: 58-64. 
Hom, P. W. \& Griffeth, R. W. 1995. Employee turnover. Ohio: South-Western College.

Hom, P. W. \& Griffeth, R. W., \& Sellaro, C. L., 1984. The validity of Mobley's (1977) model of employee turnover. Organizational Behavior and Human Performance, 34 , 141-174.

House, R. J. 1988. Power and personality in complex organizations. In Cummings, L. L. \& Staw, B. M. (Eds.), Research in Organizational Behavior, 10: 305-357.

Isabella, Lynn A. 1989. Downsizing: survivors' assessment, Business Horizons, MayJune: pp 35-41

Iverson, R. D. 1996. Employee acceptance of organizational change: the role of organizational commitment. International Journal of Human Resource Management, $7(1): 121-148$.

Iverson, R. D., Deery, S. J.. \& Erwin, P. J. 1995. Absenteeism in the health services sector: A casual model and intervention strategies. In P. Riedel and A. Preston (Eds), Managing absenteeism: Analysing and preventing labour absence. Canberra: AGPS.

Iverson, R. D., \& Pullman, J. A. (2000). Determinants of voluntary turnover and layoffs in an environment of repeated downsizing following a merger: an event history analysis. Journal of Management, 26: 977-1003.

Kanter, R. M. 1979. Power and failures in management circuits. Harvard Business Review, 57(4): 65-75.

Ket de Vries, M. F. R., \$ Balazs, K. 1997. The downside of downsizing. Human Relations, 50: 11-50.

March, James G. \& Simon, H. A. 1958. Organizations, New-York Wiley Pub. Co.

McClelland, D. C. 1975. Power: The Inner Experience, New York: Irvington Press.

Meyer, John P., Allen, Natalie J. \& Smith, Catherine A. 1993. Commitment to organizations and occupations: Extension and test of a three-component conceptualization. Journal of Applied Psychology, 78(4): 538-551.

Mayer, R. C., Davis, J. H., \& Schoorman, F. D. 1995. An integrative model of organizational trust. Academy of Management Review, 20: 709-734.

Meyer, J. P. \& Allen, N. J. 1991. A three-component conceptualization of organizational commitment. Human Resource Management Review, 1: 61-98.

Meyer, J. P., Paunonen, S., Gallatly. V., Goffin, I. R. \& Jackson, D. N. 1989.

Organizational commitment and job performance: it is the nature of the commitment that counts. Journal of Applied Psychology, 74(1): 152-156. 
Meyer, John, P. \& Allen, N.J., 1984. Testing the ASide-Bet Theory of organizational commitment: Some Methodological considerations. Journal of Applied Psychology, 69: 372-378.

Mishra, A. K. (1996) Organizational responses to crisis: The centrality of trust. In R. M. and T. R. Tyler (Eds.), Trust in Organizations: Frontiers of theory and research: 261286. Thousand Oaks, CA: Sage.

Mishra, A. K. \& Spreitzer, G. M. 1998. Explaining how survivors respond to downsizing: The role of trust, empowerment, justice, and work redesign. Academy of management Review, 23 (3): 568-588.

Mishra, K. E.. Spreitzer, G. M. \& Mishra, A. K. 1998. Preserving employee morale during downsizing. Sloan Management Review, Winter: 83-95.

Mone, M. 1994. Relationship between self-concepts, aspirations, emotional responses and intent to leave a downsizing organization. Human Resource Management, 33: 28198

Mottaz, C.J., 1988. Determinants of organizational commitment", Human Relations, 41: 467-482

Mowday, R., Steers, R. \& Porter, L. W., 1979. The measurement of organizational commitment. Journal of Vocational Behavior, 14: 224-247.

Mowday, R., Steers, R. \& Porter, L. W., 1982. Organizational linkages: The psychology of commitment, absenteeism, and turnover. San Diego, CA: Academic Press.

Mueller, C. W., Price, J. L., Boyer, M., \& Iverson, R. D. 1994. Employee attachment and noncoercive conditions of work: The case of dental hygienists. Work and Occupations, 21(2): 179-212.

Mueller, C. W., \& Price, J. L. 1990. Economic, psychological, and sociological determinants of voluntary turnover. Journal of Behavioral Economics, 19: 321-335.

Mueller, C. W., Price, J. L., \& Iverson, R. D. 1989. An event history analysis of voluntary and involuntary turnover. Paper presented at $49^{\text {th }}$ Annual Meeting of the Academy of Management. Washington, D. C.

Niehoff, B. P., Moorman, R. H., Blakely. G. \& Fuller, J. 2001. The influence of empowerment and job enrichment on employee loyalty in a downsizing environment, Group \& Organization Management, 26 (1): 93-113.

O'Reily, C. A. \& Chatman, J. 1986. Organizational commitment and psychological attachment: The effects of compliance, identification and internalization on prosocial behavior. Journal of Applied Psychology, 71: 361-378 
Oldham, G. R. 1976. The motivational strategies used by supervisors relationships to effectiveness indicators. Organizational Behavior and Human performance, 16: 66-86.

Porter, L. W., Crampton, W. J. and Smith, F. W. 1976. "Organizational commitment and managerial turnover: longitudinal study". Organizational Behavior and Human Performance, 15: 87-98

Porter, L. W. \& Steers, R. M. 1973. Organizational, work and personal factors in employee turnover and absenteeism. Psychological Bulletin, 80: 151-176.

Porter, L. W., \& Steers, R. M., Mowday, R. T., \& Boulian, P. V. 1974. Organizational commitment, job satisfaction ad turnover among psychiatric technicians. Journal of Applied Psychology, 59: 603-609.

Price, J. L. \& Mueller, C. W. 1986. Absenteeism and turnover of hospital employees. Greenwich, CT: JAI Press.

Ryan, Lisa and Keith Macky. 1988. Downsizing organizations: Uses, outcomes and strategies." Asia Pacific Journal of Human Resources, 36: 29-45.

Salanick, G. \& Pfeffer, J. 1978. A social information processing approach to job and task design. Administrative Science Quarterly, 23: 224-253

Shaw, J. D., Delery, J. E., Jenkins, G. D., \& Gupta, N. 1998. An organizational-level analysis of voluntary and involuntary turnover. Academy of Management Journal, 41(5): 511-525.

Steers, R. M.1977. Antecedents and outcomes of organizational commitment. Administrative Science Quarterly, 22: 46-56

Strauss, G., 1977. Managerial Practices. In: J. R. Hackman \& L. J. Suttle (eds.). Improving life at work: Behavioral science approaches to organizational change (pp. 297-362). Santa Monica CA: Goodyear.

Schwartz, S. and Tessler, R., 1972. A test of a model for reducing measured attitudebehavior discrepancies. Journal of Personality and Social Psychology, 24: 225-236.

Taber, T. D., Walsh, J. T., \& Cooke, R. A. 1979. Developing a community-based program of reducing the social impact of a plant closing. Journal of Applied Behavioral Science, 15: 133-155.

Thomas, K. W. \& Velthouse, B. A. 1990. Cognitive elements of empowerment: An interpretive model of intrinsic motivation. Academy of Management review, 15(4): 666681.

Wager, T., Consequences of work force reduction: Some employer and union evidence. Journal of Labor Research, 22(4): 851-862. 
Wanberg, Connie, Larry Bunce, and Mark Gavin. 1999. Perceived fairness of layoffs among individuals who Have Been Laid Off: A Longitudinal Study." Personnel Psychology 52: 59-84.

Wiener, Y.1982. Commitment in organizations: A normative view. Academy of Management Review 7 (3): 418-428.

Wiener, Y., \& Gechman, A. G. 1977. Commitment: A behavioral approach to job involvement. Journal of Vocational Behavior, 10: 47-52.

Weiner, Y. and Verdi, Y. 1980. Relationships between job, organization, and career commitments and work outcomes-An integrative approach", Organizational Behavior and Human Performance, Vol. 26, 81-96.

Zemke, R \& Schaaf, D. 1989. The service edge: 101 companies that profit from customer care. New York, N. Y.

American Library. 
Table 1 - Job Redesign ( means, standard of deviations and correlations)

\begin{tabular}{|c|c|c|c|c|c|c|c|c|c|}
\hline \multirow{2}{*}{ Scale Items } & \multirow[b]{2}{*}{ Mean } & \multirow[b]{2}{*}{$\begin{array}{l}\text { Std. } \\
\text { Dev }\end{array}$} & \multicolumn{7}{|c|}{ Correlations } \\
\hline & & & 1 & 2 & 3 & 4 & 5 & 6 & 7 \\
\hline $\begin{array}{l}\text { 1. Opportunity to use a variety of my } \\
\text { skills (task variety) }\end{array}$ & 4.3256 & 0.7584 & 1.00 & & & & & & \\
\hline $\begin{array}{l}\text { 2. Opportunity to complete an entire task } \\
\text { that I can call my own (Task Identity) }\end{array}$ & 3.9844 & 0.7275 & $0.28^{*}$ & 1.00 & & & & & \\
\hline $\begin{array}{l}\text { 3. Freedom to schedule my own work } \\
\text { (autonomy) }\end{array}$ & 4.0233 & 0.8537 & $0.27^{*}$ & $0.36^{*}$ & 1.00 & & & & \\
\hline $\begin{array}{l}\text { 4. Freedom to perform my job in the } \\
\text { manner I see fit (task autonomy) }\end{array}$ & 4.2558 & 0.7060 & $0.22^{* *}$ & $0.33^{*}$ & $0.52^{*}$ & 1.00 & & & \\
\hline $\begin{array}{l}\text { 5. A job in which I can tell how well I am } \\
\text { doing (feedback) }\end{array}$ & 4.1977 & 0.8235 & $0.32^{*}$ & - & - & - & 1.00 & & \\
\hline $\begin{array}{l}\text { 6. Opportunity to experience a sense of } \\
\text { community by working with cooperative } \\
\text { workers }\end{array}$ & 4.1628 & 0.7493 & - & - & - & - & $0.65^{*}$ & 1.00 & \\
\hline $\begin{array}{l}\text { 7. Additional training and technology to } \\
\text { handle the increasing demand of my job }\end{array}$ & 4.1628 & 0.8521 & $0.28^{*}$ & & $0.22^{* *}$ & & $0.25^{* *}$ & $0.35^{*}$ & 1.00 \\
\hline
\end{tabular}

*Significant a t the 0.01 level. ${ }^{* *}$ Significant at the 0.05 
Table 2 - Empowerment (means, standard deviation, correlations and alphas)

\begin{tabular}{|c|c|c|c|c|c|c|c|c|c|c|}
\hline $\begin{array}{l}\text { Meaningfulness }(\text { mean }=4.2273, \text { std. dev. }=0.7724, \alpha \\
=0.8904)\end{array}$ & Mean & $\begin{array}{l}\text { Std. } \\
\text { Dev. }\end{array}$ & Alpha & $\begin{array}{l}\text { Factor } \\
1\end{array}$ & $\begin{array}{l}\text { Factor } \\
2\end{array}$ & Factor 3 & Factor 4 & 1 & $\begin{array}{l}\text { Correlation } \\
\quad 2\end{array}$ & 3 \\
\hline 1. The work I do is important to me. & 4.3182 & 0.8782 & 0.8930 & 0.0453 & 0.8641 & -0.0309 & 0.1450 & 1.0000 & & \\
\hline 2. My job activities are personally meaningful to me. & 4.1011 & 0.8534 & 0.8097 & 0.0341 & 0.9240 & -0.0391 & 0.0222 & $\begin{array}{l}0.7036 \\
(0.0001)\end{array}$ & 1.0000 & \\
\hline 3. The work I do is meaningful to me & 4.2584 & 0.8192 & 0.8286 & 0.0453 & 0.9198 & 0.0117 & -0.0753 & $\begin{array}{l}0.6785 \\
(0.0001)\end{array}$ & $\begin{array}{l}0.8074 \\
(0.0001)\end{array}$ & 1.0000 \\
\hline $\begin{array}{l}\text { Competence }(\text { mean }=4.5019, \text { std. dev. }=0.4797, \alpha= \\
0.7404)\end{array}$ & & & & & & & & 4 & 5 & 6 \\
\hline 4. I am confident of my ability to do my job. & 4.6742 & 0.4713 & 0.6336 & -0.0022 & 0.1815 & 0.1120 & 0.8351 & 1.0000 & & \\
\hline $\begin{array}{l}5 . \text { I am self-assured about my capabilities to perform my } \\
\text { work activities. }\end{array}$ & 4.6067 & 0.5355 & 0.6043 & -0.0283 & 0.0046 & 0.0239 & 0.8881 & $\begin{array}{l}0.6121 \\
(0.0001)\end{array}$ & 1.0000 & \\
\hline 6.I have mastered the skills necessary for my job. & 4.2247 & 0.7347 & 0.7555 & -0.1443 & -0.1063 & 0.3162 & 0.7117 & $\begin{array}{l}0.4763 \\
(0.0001)\end{array}$ & $\begin{array}{l}0.4871 \\
(0.0001)\end{array}$ & 1.0000 \\
\hline $\begin{array}{l}\text { Self-determination }(\text { mean }=3.9026, \text { std. Dev. }= \\
0.8012, \alpha=0.8512)\end{array}$ & & & & & & & & 7 & 8 & 9 \\
\hline $\begin{array}{l}\text { 7. I can decide on my own how to go about doing my } \\
\text { work. }\end{array}$ & 4.2135 & 0.8044 & 0.9146 & -0.0352 & 0.0107 & 0.8534 & 0.1913 & 1.0000 & & \\
\hline $\begin{array}{l}\text { 8. I have considerable opportunity for independence } \\
\text { and freedom in how I do my job. }\end{array}$ & 3.8090 & 0.9756 & 0.6789 & 0.3352 & 0.0144 & 0.8430 & 0.0917 & $\begin{array}{l}0.5883 \\
(0.0001)\end{array}$ & 1.0000 & \\
\hline $\begin{array}{l}\text { 9. I have significant autonomy in determining how I do } \\
\text { my job. }\end{array}$ & 3.6450 & 0.9486 & 0.7322 & 0.4698 & 0.0042 & 0.7489 & 0.1773 & $\begin{array}{l}0.5209 \\
(0.0001)\end{array}$ & $\begin{array}{l}0.8430 \\
(0.0001)\end{array}$ & 1.0000 \\
\hline Impact $($ mean $=3.3258$, std. Dev. $1.0224, \alpha=0.8644)$ & & & & & & & & 10 & 11 & 12 \\
\hline $\begin{array}{l}\text { 10. My impact on what happens in my department is } \\
\text { great. }\end{array}$ & 3.6292 & 1.1219 & 0.9329 & 0.7075 & 0.0159 & 0.3659 & -0.0770 & 1.0000 & & \\
\hline $\begin{array}{l}\text { 11. I have a great deal of influence over what happens } \\
\text { in my department. }\end{array}$ & 3.3146 & 1.2022 & 0.6992 & 0.9464 & 0.0520 & 0.0614 & -0.1002 & $\begin{array}{l}0.6351 \\
(0.0001)\end{array}$ & 1.0000 & \\
\hline $\begin{array}{l}\text { 12. I have a great deal of control over what happens in } \\
\text { my department. }\end{array}$ & 3.0337 & 1.1327 & 0.7757 & 0.9102 & 0.0688 & 0.1116 & -0.0231 & $\begin{array}{l}0.5376 \\
(0.0001)\end{array}$ & $\begin{array}{l}0.8600 \\
(0.0001)\end{array}$ & 1.0000 \\
\hline
\end{tabular}

Probabilities are in parentheses. 
Table 3 - Affective Commitment (means, standard deviation, alpha and correlations)

\begin{tabular}{|c|c|c|c|c|c|c|c|c|c|c|c|c|}
\hline & & & & & & & Corre & tion & & & & \\
\hline $\begin{array}{l}\text { Affective Commitment } \\
(\alpha=0.8877)\end{array}$ & Mean & $\begin{array}{l}\text { Std. } \\
\text { Dev. }\end{array}$ & Alpha & Factor 1 & Factor 2 & Factor 3 & 1 & 2 & 3 & 4 & 5 & 6 \\
\hline $\begin{array}{l}\text { 1. I would be very happy to spend the } \\
\text { rest of my career with this organization. }\end{array}$ & 3.7528 & 1.1209 & 0.8750 & 0.2721 & 0.6776 & 0.2996 & $\begin{array}{l}1.0000 \\
(0.0001)\end{array}$ & & & & & \\
\hline $\begin{array}{l}\text { 2. I really feel as if this organization=s } \\
\text { problems are my own. }\end{array}$ & 2.6180 & 1.1727 & 0.8849 & 0.3922 & 0.5703 & -0.1170 & $\begin{array}{l}0.3942 \\
(0.0001)\end{array}$ & $\begin{array}{l}1.0000 \\
(0.0000)\end{array}$ & & & & \\
\hline $\begin{array}{l}\text { 3. I feel a sense of belonging to my } \\
\text { organization. }\end{array}$ & 3.3820 & 1.1629 & 0.8580 & 0.3188 & 0.7845 & 0.0221 & $\begin{array}{l}0.5527 \\
(0.0001)\end{array}$ & $\begin{array}{l}0.5165 \\
(0.0001)\end{array}$ & $\begin{array}{l}1.0000 \\
(0.0001)\end{array}$ & & & \\
\hline $\begin{array}{l}\text { 4. I feel emotionally attached to this } \\
\text { organization. }\end{array}$ & 3.2472 & 1.2181 & 0.8632 & 0.2237 & 0.8108 & -0.0145 & $\begin{array}{l}0.4864 \\
(0.0001)\end{array}$ & $\begin{array}{l}0.5681 \\
(0.0001)\end{array}$ & $\begin{array}{l}0.6706 \\
(0.0001)\end{array}$ & $\begin{array}{l}1.0000 \\
(0.0000)\end{array}$ & & \\
\hline $\begin{array}{l}\text { 5. I feel like I am a part of the family at } \\
\text { my organization. }\end{array}$ & 3.2889 & 1.1773 & 0.8608 & 0.1693 & 0.8540 & -0.1057 & $\begin{array}{l}0.5699 \\
(0.0001)\end{array}$ & $\begin{array}{l}0.4737 \\
(0.0001)\end{array}$ & $\begin{array}{l}0.7258 \\
(0.0001)\end{array}$ & $\begin{array}{l}0.6563 \\
(0.0001)\end{array}$ & $\begin{array}{l}1.0000 \\
(0.0000)\end{array}$ & \\
\hline $\begin{array}{l}\text { 6. This organization has a great deal of } \\
\text { personal meaning for me. }\end{array}$ & 3.0900 & 1.1836 & 0.8654 & 0.5520 & 0.6069 & 0.0783 & $\begin{array}{l}0.6850 \\
(0.0001)\end{array}$ & $\begin{array}{l}0.5081 \\
(0.0001)\end{array}$ & $\begin{array}{l}0.5857 \\
(0.0001)\end{array}$ & $\begin{array}{l}0.5598 \\
(0.0001)\end{array}$ & $\begin{array}{l}0.5688 \\
(0.0001)\end{array}$ & $\begin{array}{l}1.00 \\
(0.000)\end{array}$ \\
\hline
\end{tabular}

Probabilities are in parentheses 
Table. 4. Correlation between Affective commitment, Job Redesign and Employee Empowerment

\begin{tabular}{|c|c|c|c|c|c|c|}
\hline & 1 & 2 & 3 & & 5 & 6 \\
\hline \multirow[t]{2}{*}{ 1. Affective Commitment } & 1.0000 & & & & & \\
\hline & $(.00001)$ & & & & & \\
\hline \multirow[t]{2}{*}{ 2. Job Redesign } & .03292 & 1.0000 & & & & \\
\hline & $(.7634)$ & $(.00001$ & & & & \\
\hline \multicolumn{7}{|l|}{ Employee Empowerment } \\
\hline \multirow[t]{2}{*}{ 3. Impact } & .37218 & .02857 & 1.0000 & & & \\
\hline & $(0.0003)^{*}$ & $(.7940)$ & $(.00001$ & & & \\
\hline \multirow[t]{2}{*}{ 4. Meaningfulness } & .39061 & .21552 & .0951 & 1.0000 & & \\
\hline & $(0.0002)^{*}$ & $(.0463)^{*}$ & $(.3781)$ & $(.00001$ & & \\
\hline \multirow[t]{2}{*}{ 5. Competence } & -.29262 & .16001 & -.10294 & .04459 & 1.000 & \\
\hline & $(.0054)^{*}$ & $(.1411)$ & $(.3371)$ & $(.6800)$ & $(.00001$ & \\
\hline \multirow[t]{2}{*}{ 6. Self-determination } & .10044 & .15922 & .44608 & .03638 & .31258 & 1.0000 \\
\hline & $(.3490)$ & $(.1431)$ & $(.0001)^{\star}$ & $(.7365)$ & $(.0029)^{*}$ & $(.00001)$ \\
\hline
\end{tabular}

Probabilities are in parentheses ${ }^{*}$ significant correlation at .05 